\title{
Effects of reductive stripping of reactive dyes on the quality of cotton fabric
}

\author{
Mohammad Gias Uddin ${ }^{\text {** }}$, Md. Mazedul Islam² and Md. Rashedul Islam
}

\footnotetext{
* Correspondence: giasdtt@gmail. com

'Department of Textile Engineering, Ahsanullah University of Science and Technology, Tejgaon I/A, Dhaka 1208, Bangladesh

Full list of author information is available at the end of the article
}

\begin{abstract}
Some common problems of textile dyeing industries include uneven or faulty dyeing and formation of color patches on the fabric surface during dyeing and downstream processing of textiles materials. Such problems in the finished quality of fabric are generally tackled through a chemical stripping process which is a common practice in dyeing industries for the deep shade batches. However, reactive dyes cannot be stripped satisfactorily from cellulosic materials due to the formation of co-valent bonds between dye and fiber. This research was undertaken using 2.5\% and 5\% bi-hetero reactive dyes on pretreated cotton fabric and dye stripping was carried out in alkali reductive stripping process. The aim of the work was to investigate the effects of dye stripping on the quality of cotton fabric. Strength loss, weight loss, pilling resistance and absorbency of stripped fabric were calculated. Though with the increase of concentration of stripping chemicals and temperature, stripping percentages were improved; processing damage to the fabric such as losses in strength, weight and pilling resistance ratings was found. In contrast, increased fabric absorbency was found due to stripping. This is explained that during stripping, alkaline solution as an intracrystalline swelling agent is effective in loosening the crystalline region of cotton in addition to the amorphous region. Stripping agent can also attack such crystalline region. As a result, cotton fiber can release maximum number of hydroxyl groups which previously formed covalent bonds. This is the reason behind the stripped fabric having more water absorbency.
\end{abstract}

Keywords: Reductive stripping; Fabric quality; Strength loss; Weight loss; Pilling; Fabric absorbency

\section{Introduction}

Around 10,000,000 tons of synthetic dyes are annually used in the world (Ghorpade et al. 2000; Goodarzian and Ekrami 2010; Saravanan et al. 2014) by various industries for coloring numerous materials. Textile industry accounts for two-thirds of the total dyestuff market (Anouzla et al. 2009; Riu et al. 1998; Shertate and Thorat 2013). Over 10,000 dyes with an annual production of over $7 \times 10^{5}$ metric tons are commercially available for use by this industry (Campos et al. 2001). However, some common problems of textile dyeing industries include uneven or faulty dyeing and formation of color patches on the fabric surface during dyeing and downstream processing of textiles materials (Fono and Montclair 1980; Ogulata and Balci 2007). Such problems in the finished quality of fabric are generally tackled through a chemical stripping process which is a common practice in dyeing industries for the deep shade batches. 
Stripping is one of the reproduction processes, used in textile finishing, removing dyes from colored fabric. The process is either termed as 'back stripping' or 'destructive stripping'. In back stripping only the depth of shade is changed while in destructive stripping the dyes are chemically altered (Ali et al. 2012; Fono and Montclair $1980)$, such as dyes containing an azo group $(-\mathrm{N}=\mathrm{N}-)$ can be chemically reduced to an almost colorless amine compound by using chemical reducing agents. Sometimes for the analysis of dyes or dyed fabrics, dyes may need to be stripped from the surface by either destructive or non-destructive methods. Non-destructive stripping is essential when the amount of dye on the fiber has to be estimated, or the dye has to be identified or analyzed by techniques such as chromatography. Laboratory methods for stripping dyes seldom mirror those used in bulk processing, since these are usually destructive methods based on strongly reductive or oxidative methods (Park and Shore 2004). Depending on the individual dyes, complete chemical stripping may be carried out in one of the four ways: reduction only; reduction followed by oxidation; oxidation only; and oxidation followed by reduction (Aspland 1997). As sodium chlorite or peroxide solutions are used in oxidizing process, decreasing in strength of textile material is highly possible, so alkali reductive application is generally preferred for the stripping of reactive dyes. The mechanism of reductive stripping depends on the type of dyes, fibers and reducing agents. Dyes are commonly stripped from fabric using a reducing agent, and a stripping assistant which is used to enhance the stripping efficiency of a reducing agent. Various chemical combinations of reducing agents and stripping assistants are being used in stripping liquids to strip the dye from fabric (Chavan 1969).

The reductive stripping occurs from chemical reactions in case of cellulose dyed with reactive dyes. The chemical bonds on the chromophore group of reactive dyes are tried to break in order to dissolve of colorfulness. Reactive dyes cannot be stripped satisfactorily from cellulosic materials, due to the formation of co-valent bond between dye and fiber (Choudhury 2006). The stripping performance depends on several factors: raw materials, type of dyestuff, method of dyeing and stripping, type of stripping agents and auxiliaries, and working parameters such as time, temperature etc. Achieving the expected efficiency in the application of stripping process is a very important aspect for the success of reproduction (Ogulata and Balci 2007). However, alkaline reductive stripping also affects the quality of fabric as harsh chemicals such as sodium hydrosulphite and sodium hydroxide as well as high temperature is applied in the stripping process, but the effects are at what extent? The aim of this study was to evaluate such effects of dye stripping on the quality of fabric.

\section{Methods}

\section{Materials}

Pretreated (Scoured-bleached) cotton fabric (Single jersey) of about $166 \mathrm{~g} / \mathrm{m}^{2}$ (Yarn count $25^{\mathrm{S}} \mathrm{Ne}$ ), supplied by Hi-Fashion Composite Textiles Ltd., Joydevpur, Gazipur was used throughout the study. Bi-hetero type (Flurotriazine and vinyl sulphone) reactive dyes: Novacron Red TS-3B, Novacron Yellow TS-3R and Novacron Blue TS-3G supplied by Huntsman Bangladesh Ltd. was used for this research purpose. Sodium hydrosulphite supplied by Titas Spinning and Denim Company Ltd. Mawna-Bhabanipur, 
Gazipur was used as a stripping agent. All other chemicals and auxiliaries used for the experimental work were laboratory grade reagents.

\section{Dyeing process}

Dyeing was carried out on the pretreated fabric with the two shades $(2.5 \%$ and $5 \%)$ using combination shade in exhaust method in the IR sample dyeing machine at $60^{\circ} \mathrm{C}$ for $40 \mathrm{~min}$, keeping material to liquor ratio $1: 10$ and $\mathrm{pH} 10.5$. Then after washing, the dyed fabric was neutralized with $1 \mathrm{~g} / \mathrm{l}$ acetic acid followed by soaping with $1 \mathrm{~g} / \mathrm{l}$ Dekol $\mathrm{SN}$ at $80^{\circ} \mathrm{C}$ for $5 \mathrm{~min}$. Dyeing recipes for different shade\% of reactive dyes was given in Table 1 .

\section{Stripping process}

Eight different stripping operations (see Table 2) were carried out for each shade\% in the sample dyeing machine using material to liquor ratio 1:15 for $30 \mathrm{~min}$.

Table 1 Dyeing recipes using $2.5 \%$ and $5 \%$ reactive dyes

\begin{tabular}{|c|c|c|c|c|c|c|c|}
\hline \multirow[t]{2}{*}{ SI. no } & \multicolumn{3}{|l|}{ Shades } & \multicolumn{4}{|l|}{ Recipe } \\
\hline & Dyes & $\begin{array}{l}\text { Combined } \\
\text { shade }\end{array}$ & $\begin{array}{l}\text { Individual } \\
\text { shade }\end{array}$ & $\begin{array}{l}\text { Glauber's } \\
\text { salt (g/l) }\end{array}$ & $\begin{array}{l}\text { Soda ash } \\
(\mathrm{g} / \mathrm{l})\end{array}$ & $\begin{array}{l}\text { Wetting } \\
\text { agent }(g / l)\end{array}$ & $\begin{array}{l}\text { Sequestering } \\
\text { agent }(\mathbf{g} / \mathrm{l})\end{array}$ \\
\hline \multirow[t]{3}{*}{1.} & $\begin{array}{l}\text { Novacron red } \\
\text { TS-3B }\end{array}$ & $2.5 \%$ & $2.0 \%$ & 60 & 14 & 1 & 1 \\
\hline & $\begin{array}{l}\text { Novacron } \\
\text { yellow TS-3R }\end{array}$ & & $0.4 \%$ & & & & \\
\hline & $\begin{array}{l}\text { Novacron blue } \\
\text { TS-3G }\end{array}$ & & $0.1 \%$ & & & & \\
\hline \multirow[t]{3}{*}{2.} & $\begin{array}{l}\text { Novacron red } \\
\text { TS-3B }\end{array}$ & $5 \%$ & $4.0 \%$ & 100 & 18 & & \\
\hline & $\begin{array}{l}\text { Novacron } \\
\text { yellow TS-3R }\end{array}$ & & $0.8 \%$ & & & & \\
\hline & $\begin{array}{l}\text { Novacron blue } \\
\text { TS-3G }\end{array}$ & & $0.2 \%$ & & & & \\
\hline
\end{tabular}

Table 2 Stripping recipes

\begin{tabular}{llll}
\hline Stripping operations & Temperature $\left({ }^{\circ} \mathbf{C}\right)$ & $\begin{array}{l}\text { Conc. of sodium } \\
\text { hydrosulphite }(\mathbf{g} / \mathbf{l})\end{array}$ & $\begin{array}{l}\text { Conc. of caustic } \\
\text { soda }(\mathbf{g} / \mathbf{l})\end{array}$ \\
\hline 1. & 80 & 5 & 2.5 \\
2. & 5 & 5 \\
3. & 10 & 5 \\
4. & 10 & 10 \\
5. & 100 & 5 & 2.5 \\
6. & & 5 & 5 \\
7. & 10 & 5 \\
8. & 10 & 10 \\
\hline
\end{tabular}




\section{Stripping percentage}

The color yields of both dyed and stripped fabric were determined in terms of K/S value by a dual beam reflectance spectrophotometer. The stripping percentage was calculated using equation (1) (Ali et al. 2012).

$$
\text { Stripping percentage }=\frac{[\mathrm{K} / \mathrm{S} \text { value of dyed sample }-\mathrm{K} / \mathrm{S} \text { value of stripped sample }}{\mathrm{K} / \mathrm{S} \text { value of dyed sample }} \times 100
$$

\section{Fabric quality evaluation}

\section{Strength loss}

Bursting strength of dyed and stripped fabric was carried out in ISO 13938-1:1999 method by Bursting Strength Tester. Then strength loss of the stripped sample was measured using equation (2).

$$
\text { Strength loss percentage }=\frac{(\text { Fabric strength before stripping }- \text { Fabric strength after stripping })}{(\text { Fabric strength before stripping })} \times 100
$$

\section{Weight loss}

Loss in weight of stripped sample was measured by difference in weight before and after treatment using equation (3).

$$
\text { Weight loss percentage }=\frac{(\text { Fabric weight before stripping }- \text { Fabric weight after stripping })}{(\text { Fabric weight before stripping })} \times 100
$$

\section{Pilling}

Pilling resistance of stripped fabric samples was assessed in SN 198525 method using Martindale Abrasion and Pilling Tester.

\section{Fabric water absorbency}

Vertical wicking test of fabric was carried out using "Ciba" Test Method reported by Kate Spade \& Company (2014). The $15 \mathrm{~cm} \times 2.5 \mathrm{~cm}$ strips of samples (Both in wale and coarse direction) was lowered to touch the water reservoir at which moment timer was started, and the position of water front line $(\mathrm{cm})$ over 5 min was recorded.

\section{Results and discussion}

\section{Stripping percentage}

Stripping percentages of the dyed fabrics for $2.5 \%$ and $5 \%$ shades were displayed in Figures 1 and 2, respectively.

From Figure 1, for $2.5 \%$ shade, it was found that stripping percentages of dyed fabrics increased gradually with the increase of concentration of stripping chemicals (Hydrose and caustic soda) when fabrics were stripped both at $80^{\circ} \mathrm{C}$ and $100^{\circ} \mathrm{C}$. Stripping percentages were also found higher at $100^{\circ} \mathrm{C}$ than $80^{\circ} \mathrm{C}$ under each combination of stripping chemicals. As the temperature of the stripping operation was more, the stripping was more. Both at $80^{\circ} \mathrm{C}$ and $100^{\circ} \mathrm{C}$ temperature when concentration of caustic soda was doubled from $2.5 \mathrm{~g} / \mathrm{l}$ to $5 \mathrm{~g} / \mathrm{l}$ with $5 \mathrm{~g} / \mathrm{l}$ hydrose as well as from $5 \mathrm{~g} / \mathrm{l}$ to $10 \mathrm{~g} / \mathrm{l}$ with 10 g/l hydrose, stripping percentages were slightly increased. From Figure 2, similar 


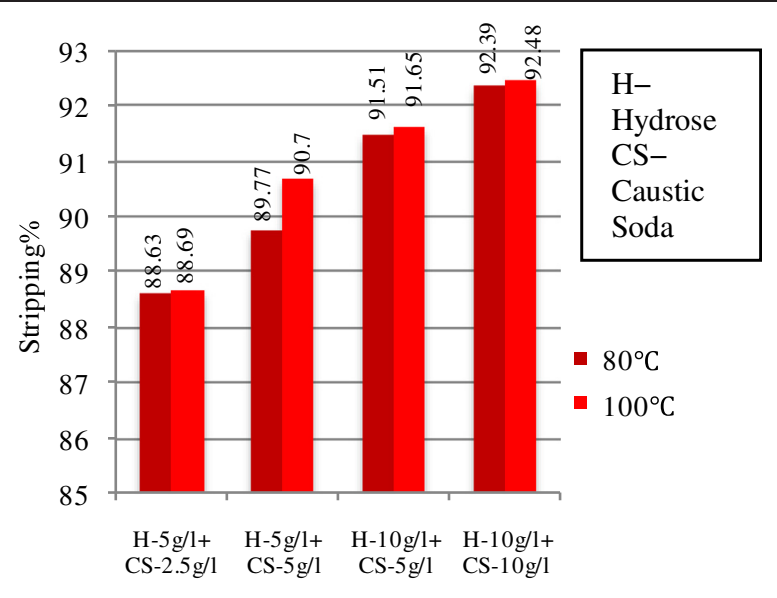

Concentration of stripping chemicals

Figure 1 Stripping percentages of dyed fabric (2.5\% shade).

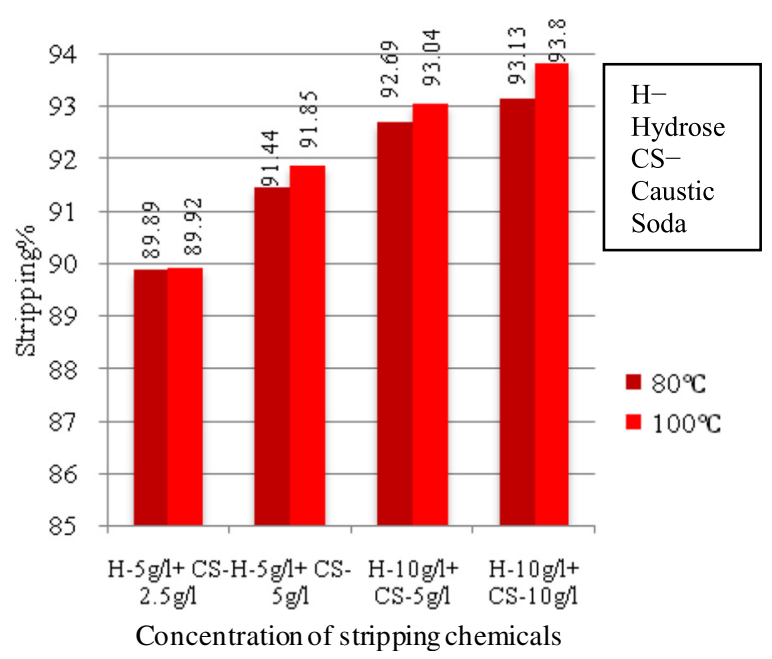

Figure 2 Stripping percentages of dyed fabric ( $5 \%$ shade).

trends were found for $5 \%$ shade. Using $10 \mathrm{~g} / \mathrm{l}$ hydrose and $10 \mathrm{~g} / \mathrm{l}$ caustic soda and stripping at $100^{\circ} \mathrm{C}$, the maximum stripping for $2.5 \%$ and $5 \%$ shades were found $92.8422 \%$ and 93.801\%, respectively.

\section{Strength loss}

Strength loss percentages of the dyed fabrics for $2.5 \%$ and $5 \%$ shades were shown in Figures 3 and 4, respectively.

In case of $2.5 \%$ shade, strength loss percentages were increased gradually with the increase of concentration of stripping chemicals both at $80^{\circ} \mathrm{C}$ and $100^{\circ} \mathrm{C}$ as shown in Figure 3. In between $80^{\circ} \mathrm{C}$ and $100^{\circ} \mathrm{C}$, it was noticed that strength loss percentages were higher at $100^{\circ} \mathrm{C}$ when the fabrics were treated in same parameter. Here, the sample dyed with $2.5 \%$ shade when treated with $10 \mathrm{~g} / \mathrm{l}$ hydrose and $10 \mathrm{~g} / \mathrm{l}$ caustic soda at $100^{\circ} \mathrm{C}$ showed maximum strength loss of $9.23 \%$ in comparison to the maximum strength loss of 


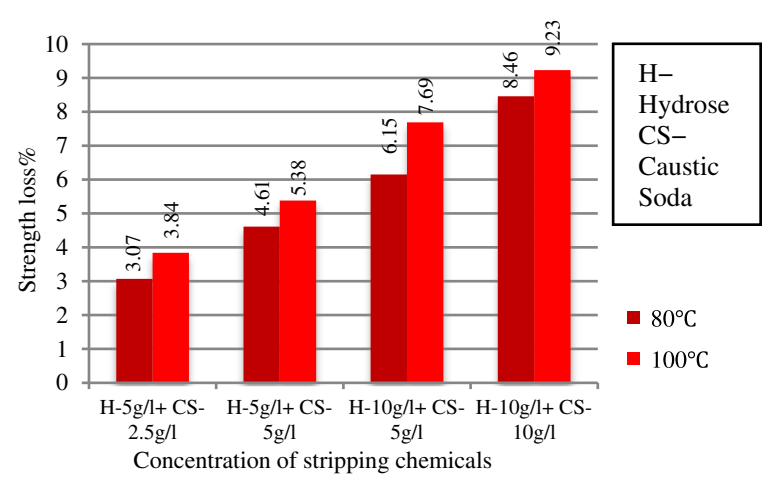

Figure 3 Strength loss $\%$ of stripped samples (2.5\% shade).

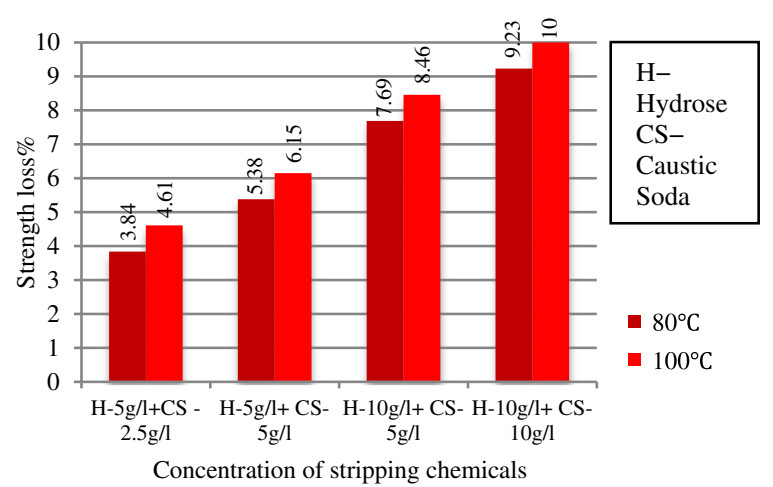

Figure 4 Strength loss\% of stripped samples (5\% shade).

$8.46 \%$ when treated at $80^{\circ} \mathrm{C}$ under the same combination of stripping chemicals. As both the temperature and stripping chemicals were comparatively more, the extent of strength loss was also found more. Again, when caustic soda was doubled from $2.5 \mathrm{~g} / \mathrm{l}$ to $5 \mathrm{~g} / \mathrm{l}$ with $5 \mathrm{~g} / \mathrm{l}$ hydrose, strength losses were increased from $3.07 \%$ to $4.61 \%$ (In case of $80^{\circ} \mathrm{C}$ ) and from 3.84 to $5.38 \%$ (In case of $100^{\circ} \mathrm{C}$ ). Similarly, increasing caustic soda from $5 \mathrm{~g} / \mathrm{l}$ to $10 \mathrm{~g} / \mathrm{l}$ with $10 \mathrm{~g} / \mathrm{l}$ hydrose resulted in increased strength loss from $6.15 \%$ to $8.46 \%$ (In case of $80^{\circ} \mathrm{C}$ ) and from $7.69 \%$ to $9.23 \%$ (In case of $100^{\circ} \mathrm{C}$ ).

For 5\% shade, similar trends of gradual increasing of strength loss with the increase of concentrations of stripping chemicals were found as shown in Figure 4 for both $80^{\circ} \mathrm{C}$ and $100^{\circ} \mathrm{C}$. The samples dyed with $5 \%$ shade when stripped using $10 \mathrm{~g} / \mathrm{l}$ hydrose and $10 \mathrm{~g} / \mathrm{l}$ caustic soda at $100^{\circ} \mathrm{C}$ showed maximum strength loss of $10.0 \%$ in comparison to the maximum strength loss of $9.23 \%$ when treated at $80^{\circ} \mathrm{C}$ under the same combination of stripping chemicals.

\section{Weight loss}

Quality of stripped fabric was also evaluated by measuring the percent weight loss. Weight loss percentages of the dyed fabrics for $2.5 \%$ and $5 \%$ shades were displayed in Figures 5 and 6 , respectively. From Figure 5, for $2.5 \%$ shade it was noticed that weight loss percentages of stripped fabrics increased with the increase of concentration of stripping chemicals when fabrics were stripped both at $80^{\circ} \mathrm{C}$ and $100^{\circ} \mathrm{C}$. The weight loss percentages were found 


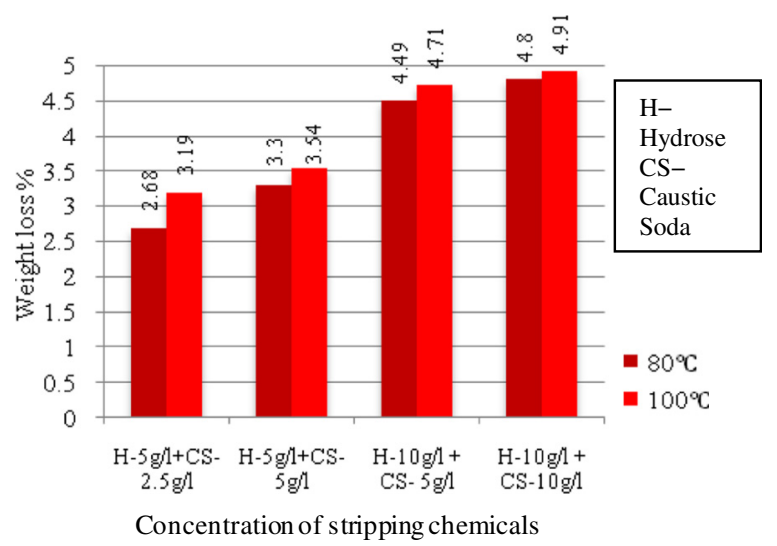

Figure 5 Weight loss\% of stripped fabric (2.5\% shade).

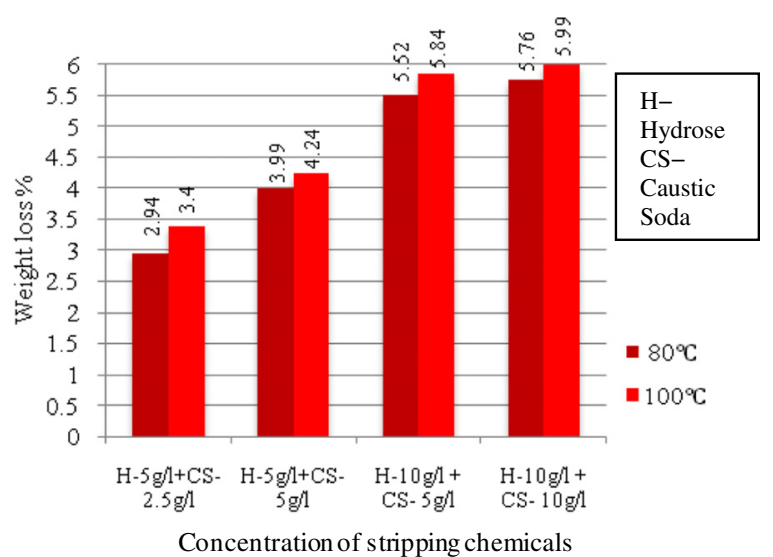

Figure 6 Weight loss $\%$ of stripped fabric ( $5 \%$ shade).

higher at $100^{\circ} \mathrm{C}$ than $80^{\circ} \mathrm{C}$ under each combination of stripping chemicals used. As the temperature of stripping operations was more, the weight loss percentage was found more. Here, the sample dyed with $2.5 \%$ shade when treated with $10 \mathrm{~g} / \mathrm{l}$ hydrose and $10 \mathrm{~g} / \mathrm{l}$ caustic soda at $100^{\circ} \mathrm{C}$ showed maximum weight loss of $4.91 \%$ in comparison to the maximum weight loss of $4.8 \%$ when treated at $80^{\circ} \mathrm{C}$ under the same combination of stripping chemicals.

In case of $5 \%$ shade, similar trend was found as shown in Figure 6 . The samples dyed with $5 \%$ shade when stripped using $10 \mathrm{~g} / \mathrm{l}$ hydrose and $10 \mathrm{~g} / \mathrm{l}$ caustic soda at $100^{\circ} \mathrm{C}$ showed maximum weight loss of $5.99 \%$ in comparison to the maximum weight loss of $5.76 \%$ when treated at $80^{\circ} \mathrm{C}$ under the same combination of stripping chemicals.

Reactive dyes are the most substantive of dyes used on cotton because of their covalent bonding with glucoside hydroxyls. As a result, these dyes are the most resistant to extraction or destruction of all dye types. An aqueous solution of a strong base is typically used to remove the dyes from the cotton fiber. Complete extraction of reactive dyes was reported from bulk cotton treated with $1.5 \%$ aqueous $\mathrm{NaOH}$ at $100^{\circ} \mathrm{C}$ for 20 min (Dockery et al. 2009). The alcohol groups on the glucose units in the cellulose backbone of cotton act as a 
weak acid and are ionized under alkaline conditions. As cotton fibers partially dissolve in concentrated sodium hydroxide at elevated temperatures, fabric strength loss occurred. As such, during alkaline dye reductive process fabric strength loss occurred. Strength loss of stripped fabric increased with the increase of stripping action provided by the elevated temperature and concentration of hydrose and caustic soda. Increased weight losses of stripped fabrics are the consequences of higher strength loss due to similar way.

\section{Pilling resistance}

\section{Ratings for dyed and stripped samples in case of $2.5 \%$ shade}

Pilling resistance ratings were found 5, 4-5 and 4 under 125, 500 and 2000 cycles respectively for fabric dyed with $2.5 \%$ dyes as shown in Figures 7 and 8 . Ratings were found similar as dyed fabric when $5 \mathrm{~g} / \mathrm{l}$ hydrose and $2.5 \mathrm{~g} / \mathrm{l}$ caustic soda combination were used at $80^{\circ} \mathrm{C}$ but ratings decreased by $1 / 2$ grade than the dyed fabric for 500 and 2000 cycles under same combination of chemicals at $100^{\circ} \mathrm{C}$. In other three combinations, ratings were found 4-5, 4, and 3-4 when treated at 125, 500 and 2000 cycles respectively for both the temperatures except the combination of $10 \mathrm{~g} / \mathrm{l}$ hydrose and $10 \mathrm{~g} / \mathrm{l}$ caustic soda at $100^{\circ} \mathrm{C}$ (Rating 3).

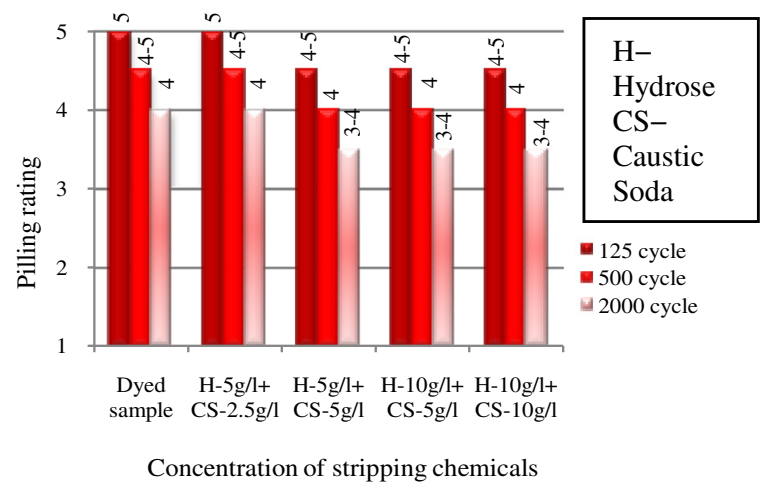

Figure 7 Pilling ratings of stripped samples at $80^{\circ} \mathrm{C}$ (2.5\% shade).

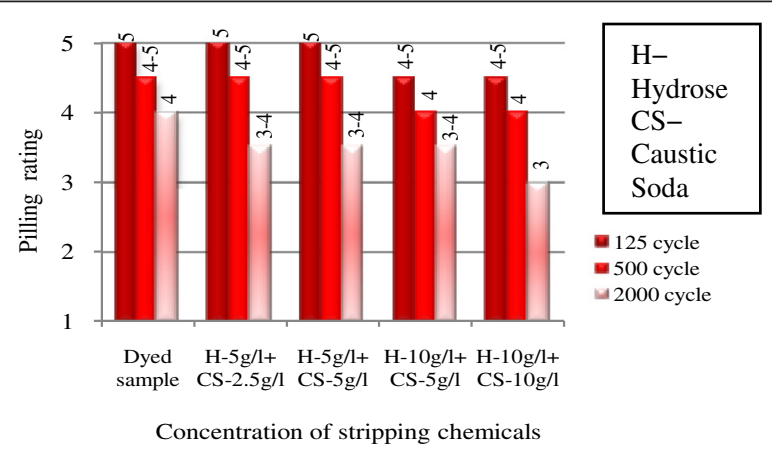

Figure 8 Pilling ratings of stripped samples at $100^{\circ} \mathrm{C}$ ( $2.5 \%$ shade). 


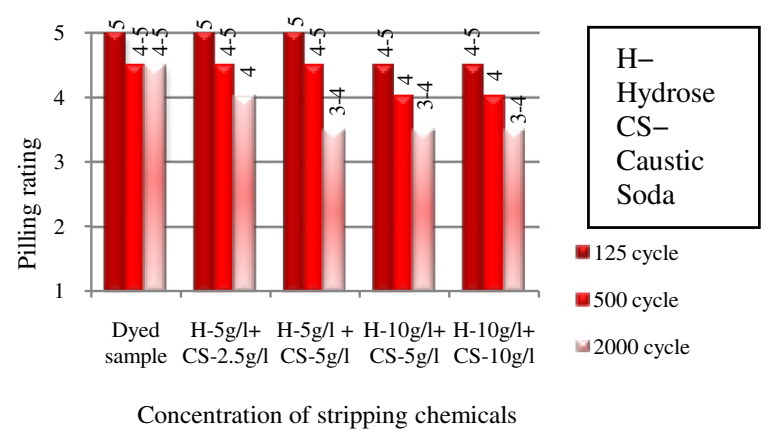

Figure 9 Pilling ratings of stripped samples at $80^{\circ} \mathrm{C}$ ( $5 \%$ shade).

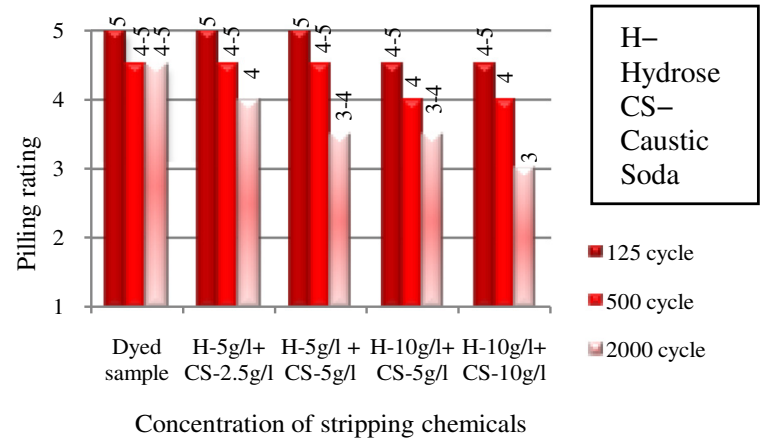

Figure 10 Pilling ratings of stripped samples at $100^{\circ} \mathrm{C}$ ( $5 \%$ shade).

\section{Ratings for dyed and stripped samples in case of $5 \%$ shade}

For $5 \%$ shade, pilling resistance ratings of dyed fabric were found 5 under 125 cycles and 4-5 under 500 and 2000 cycles as shown in Figures 9 and 10.

For both the stripping temperatures, in case of $5 \mathrm{~g} / \mathrm{l}$ hydrose and $2.5 \mathrm{~g} / \mathrm{l}$ caustic soda combination, pilling resistance ratings were 5, 4-5 and 4 under 125,500 and 2000 cycles respectively whereas for $5 \mathrm{~g} / \mathrm{l}$ hydrose and $5 \mathrm{~g} / \mathrm{l}$ caustic soda, corresponding ratings were 5, 4-5 and 3-4. When the dyed sample was treated with $10 \mathrm{~g} / \mathrm{l}$ hydrose and $5 \mathrm{~g} / \mathrm{l}$ caustic soda or $10 \mathrm{~g} / \mathrm{l}$ hydrose and $10 \mathrm{~g} / \mathrm{l}$ caustic sodacombination at both $80^{\circ} \mathrm{C}$ and $100^{\circ} \mathrm{C}$, pilling ratings were found 4-5, 4 and 3-4 under 125, 500 and 2000 cycles respectively, except rating 3 was found under 2000 cycles for $10 \mathrm{~g} / \mathrm{l}$ hydrose and $10 \mathrm{~g} / \mathrm{l}$ caustic soda combination stripping treated at $100^{\circ} \mathrm{C}$. The alkali-treated cotton surfaces appeared fuzzy and blurred at the time of reductive stripping at high temperature and so lower pilling resistance.

\section{Fabric absorbency}

The wicking test results of pretreated, dyed and stripped fabrics were shown in Table 3. The average absorbing length was found $9.5 \mathrm{~cm}$ for pretreated fabric in both wale and coarse direction, whereas it increased to $10.5 \mathrm{~cm}$ (In wale direction) and $10 \mathrm{~cm}$ (In coarse direction) for dyed fabrics and further increased in the stripped fabrics. For stripped fabrics, it ranged within $11.5 \mathrm{~cm}$ to $14 \mathrm{~cm}$ in wale direction and $11 \mathrm{~cm}$ to $13.7 \mathrm{~cm}$ in coarse direction for $2.5 \%$ shade. Again, for 5\% shade, it ranged within $11.5 \mathrm{~cm}$ to $13.9 \mathrm{~cm}$ in wale direction and $10.6 \mathrm{~cm}$ to $13.9 \mathrm{~cm}$ in coarse direction. 
Table 3 Wicking test results of pretreated, dyed and stripped fabric

\begin{tabular}{|c|c|c|c|c|c|c|c|c|c|}
\hline \multirow[t]{3}{*}{ Shade $\%$} & \multicolumn{3}{|c|}{ Stripping recipes } & \multicolumn{6}{|c|}{ Water front line $(\mathrm{cm})$} \\
\hline & \multirow{2}{*}{$\begin{array}{l}\text { Temperature } \\
\left({ }^{\circ} \mathrm{C}\right)\end{array}$} & \multirow{2}{*}{$\begin{array}{l}\text { Hydrose } \\
(\mathrm{g} / \mathrm{l})\end{array}$} & \multirow{2}{*}{$\begin{array}{l}\text { Caustic } \\
\text { Soda } \\
\text { (g/l) }\end{array}$} & \multicolumn{2}{|c|}{ Pretreated fabric } & \multicolumn{2}{|c|}{ Dyed fabric } & \multicolumn{2}{|c|}{ Stripped fabric } \\
\hline & & & & Wale & Course & Wale & Course & Wale & Course \\
\hline \multirow[t]{8}{*}{2.5} & 80 & 5 & 2.5 & 9.5 & 9.5 & 10.5 & 10 & 13.5 & 12.5 \\
\hline & & 5 & 5 & & & & & 12.25 & 12.25 \\
\hline & & 10 & 5 & & & & & 11.5 & 11 \\
\hline & & 10 & 10 & & & & & 12 & 11.5 \\
\hline & 100 & 5 & 2.5 & & & & & 13.9 & 12.9 \\
\hline & & 5 & 5 & & & & & 14 & 13.7 \\
\hline & & 10 & 5 & & & & & 12.7 & 12.1 \\
\hline & & 10 & 10 & & & & & 13.1 & 12.5 \\
\hline \multirow[t]{8}{*}{5.0} & 80 & 5 & 2.5 & & & & & 13 & 12.25 \\
\hline & & 5 & 5 & & & & & 13.5 & 13 \\
\hline & & 10 & 5 & & & & & 13.9 & 13.5 \\
\hline & & 10 & 10 & & & & & 13.4 & 13 \\
\hline & 100 & 5 & 2.5 & & & & & 12.2 & 10.65 \\
\hline & & 5 & 5 & & & & & 13 & 11.6 \\
\hline & & 10 & 5 & & & & & 11.5 & 11.5 \\
\hline & & 10 & 10 & & & & & 12 & 10.6 \\
\hline
\end{tabular}

Thus it can be said from the wicking test results that the water front line in the stripped samples was pronouncedly higher than the pretreated one. The better wettability of the stripped samples might be due to the stripping treatment under alkaline condition. In addition, the greater absorbency of the dyed fabric in comparison to the pretreated fabric was due to dyeing of cotton fabric with reactive dyes was carried out in alkaline media (Liu and Wang 2009). Both dyed and stripped fabrics were treated under different concentrations of alkali, material to liquor ratio, temperature and time; but in case of stripping process of the dyed fabrics higher concentration of alkali and temperature were used than the dyed ones and correspondingly found higher wicking distance in the stripped fabrics.

Moreover, water is an intercrystalline swelling agent which can penetrate and loosen only the amorphous region of cellulose; while alkaline solution, as an intracrystalline swelling agent affects both the amorphous and crystalline regions of cellulose. As a result, alkaline solution is effective in loosening the crystalline region of cellulose. The action of such swelling agent inherits the outer skin on cotton fibers and causes it to split and form collars; the inner cellulose layers swell rapidly the collars (Fan et al. 1987). Due to loosening of crystalline region of cellulose by swelling agents, the absorbency of the fabric towards water and dyes is increased.

It can be explained in other words. Cotton is pure cellulose, a naturally occurring polymer. Chemically it is a "cellobiose" which belongs to carbohydrate polymer, containing hydroxyl groups. These negatively charged groups attract water molecules and make cotton absorbs water well. When cotton dyed with reactive dyes, some of these $-\mathrm{OH}$ groups are occupied, which slightly reduces absorbency. During the stripping process, cotton fiber releases the maximum number of hydroxyl groups which has been formed covalent bonds with the cellulose. This is due to the dye reduction 
reaction of sodium hydrosulphite and caustic soda on the cellulose. In addition, the stripping agent can also attack the crystalline region of cotton and as a result, there may also be chances of releasing the hydroxyl groups. Basically, hydroxyl groups are responsible for water absorbency. This is the reason behind the stripped fabric having more water absorbency as well as strength loss.

Furthermore, the basic preparation processes of cotton knit fabric include scouring and bleaching. These treatments remove natural and human induced impurities, that is, noncellulosic constituents and other unwanted substances. Thus increase the affinity of cellulose for dyes and finishes. It may also be possible that any impurities remained in the fabric could not be removed at the elementary preparation processes and they also remained in the dyed fabrics, which were finally removed due to alkaline reductive stripping action. As a result, absorbency of the stripped fabric might also be increased showing higher wicking distant.

\section{Conclusions}

In this study, an investigation was carried out on alkali reductive stripping process for the cotton knit fabric dyed with the Novacron Red TS-3B, Novacron Yellow TS-3R and Novacron Blue TS-3G reactive dyes concerning the working parameters as the concentration of reducing agent and caustic soda, stripping temperature. Based on this experimental study, the conclusions drawn were:

1. Fabric strength loss percentages increased gradually with the increase of concentration of stripping chemicals and temperature of stripping bath. The sample dyed with $2.5 \%$ and $5 \%$ shades when treated with $10 \mathrm{~g} / \mathrm{l}$ hydrose and $10 \mathrm{~g} / \mathrm{l}$ caustic soda at $100^{\circ} \mathrm{C}$ showed maximum strength loss of $9.23 \%$ and $10.0 \%$ respectively.

2. Fabric weight loss percentages of stripped fabrics were increased gradually with the increase of concentration of stripping chemicals and stripping temperature. The sample dyed with $2.5 \%$ and $5 \%$ shades when treated with $10 \mathrm{~g} / \mathrm{l}$ hydrose and $10 \mathrm{~g} / \mathrm{l}$ caustic soda at $100^{\circ} \mathrm{C}$ showed maximum weight loss of $4.91 \%$ and $5.99 \%$, respectively.

3. In most cases, stripped samples showed lower pilling resistance rating than the corresponding dyed fabric.

4. Fabric absorbency was increased considerably due to stripping.

The stripping of reactive dyes from cotton knit fabric and its satisfactory performance level directly related to the processing damage to the fabric. Besides the better striping percentage, the overall fabric quality needs to be considered at the time of stripping. As stripping is a dye destruction process using harsh chemicals, there is no way to stop completely their adverse effects on fabric quality, but this can be controlled within a certain range. In case of major unevenness $5 \mathrm{~g} / \mathrm{l}$ hydrose and $5 \mathrm{~g} / \mathrm{l}$ alkali is commonly used in knit dyeing industries for full stripping of reactive dyes from cotton fabric and according to this study the fabric strength loss and weight loss can be controlled within $5 \%$ for both using such combinations.

Stripping whether partial or full should be selected at the elementary stage in the bulk production on the basis of major dyeing faults and expected target shade. In general, dyeing industries take decision of dye stripping when it becomes absolutely 
necessary for their not ok dyed fabrics. For such not ok, already rejected to delivery batches, manufacturers get ready to compromise with the quality of fabric up to a controlled limit. If stripping can be carried out under optimum alkaline condition which is just sufficient to maintain the stability of sodium hydrosulphite in the stripping bath will definitely reduce the fabric damaging effects. Unevenness can be removed from the surface of the fabric through stripping and then re-dyeing can give the fabric new look as expected shade, as if it can be said that stripping is an aspect of improving the appearance and evenness.

\section{Competing interests}

The authors declare that they have no competing interests.

\section{Authors' contributions}

MGU designed and carried out the experiments, analyzed the data as well as drafted the manuscript. All authors read and approved the final manuscript.

\section{Acknowledgement}

The authors of the paper would like to thank Mr. Rezaul Hasan (Rumman), Manager, Concept Knitting Ltd., Masco Group for his technical support.

\section{Author details}

1Department of Textile Engineering, Ahsanullah University of Science and Technology, Tejgaon I/A, Dhaka 1208, Bangladesh. ${ }^{2}$ Department of Textile Engineering, Dhaka University of Engineering and Technology, Gazipur 1700, Bangladesh.

Received: 2 February 2015 Accepted: 28 April 2015

Published online: 24 June 2015

\section{References}

Ali, S, Chathaa, S, Asghera, M, Ali, SK, \& Hussain, Al. (2012). Biological color stripping: a novel technology for removal of dye from cellulose fibers. Carbohydr Polym, 87(2), 1476-1481.

Anouzla, A, Souabi, S, Safi, M, Aboulhassan, A, Rhbal, H, \& Abrouki, Y. (2009). Valorization of steel industry wastewaters in the decolorization of dyes containing solutions. Scientific Study \& Research, 10(3), 277-284.

Aspland, JR. (1997). Textile dyeing and coloration (p. 130). Research Triangle Park, NC: American Association of Textile Chemists and Colorists.

Campos, R, Kandelbauer, A, Robra, KH, Artur, CP, \& Gubitz, GM. (2001). A rapid and sensitive method for the quantification of protein using the principle of protein-dye binding. Anal Biochem, 72, 248-254.

Chavan, RB (1969). Stripping of dyestuff from textiles, US Patent No. 3591325

Choudhury, RKA. (2006). Textile preparation and dyeing (p. 550). New Delhi, India: Oxford and IBH Publishing Ltd.

Dockery, CR, Stefan, AR, Nieuwland, AA, Roberson, SN, Baguley, BM, Hendrix, JE, \& Morgan, SL. (2009). Automated extraction of direct, reactive, and vat dyes from cellulosic fibers for forensic analysis by capillary electrophoresis. Anal Bioanal Chem, 394, 2095-2103.

Fan, LT, Gharpurag, MM, \& Lee, YH. (1987). Biotechnology monograph: cellulose hydrolysis volume vi (p.14-17, 66). New York: Springer Verlag, Berlin.

Fono, A, \& Montclair, NJ (1980 October 14). New process of color stripping dyed textile fabrics. US Patent No. 4227881.

Ghorpade, B, Darvekar, M, \& Vankar, PS. (2000). Ecofriendly cotton dyeing with Sappan wood dye using ultrasound energy. Colorage, 45(1), 27-30.

Goodarzian, H, \& Ekrami, E. (2010). Extraction of dye from madder plant (Rubia tictorium L) and dyeing of wool. World Appl Sci J, 9(4), 434-436.

Kate Spade \& Company. (2014 February). Standard test methods: wicking test methods, p. 6. Retrieved December 29, 2014 from https://portal.katespadeconnect.com/documents/10113/1288847/Standard+Test+Methods

Liu, J, \& Wang, F-m. (2009). Effect of alkalization treatment on structure and properties of bleached kapok yarn. Journal of Xi'an Polytechnique University, 23(2), 386-394.

Ogulata, RT, \& Balci, O. (2007). Investigation of the stripping process of the reactive dyes using organic sulphur reducing agents in alkali condition. Fibers Polym, 8(1), 25-36.

Park, J, \& Shore, J. (2004). Practical dyeing volume ii. England: The Society of Dyers and Colorists.

Riu, J, Schonsee, I, \& Barcelo, D. (1998). Determination of sulfonated azo dyes in groundwater and industrial effluents by automated solid-phase extraction followed by capillary electrophoresis/mass spectrometry. J Mass Spectro, 33, 653-663.

Saravanan, P, Chandramohan, G, Mariajancyrani, J, \& Kiruthikajothi, K. (2014). Eco-friendly dyeing of wool fabric with a natural dye extracted from barks of Odinawodier. Der Chemica Sinica, 5(1), 28-33.

Shertate, RS, \& Thorat, PR. (2013). Biotransformation of sulphonated azo dye direct red 5B by marinobacter sp.dr-7- a bioremedial aspect in marine environment. Int J Pharma Bio Sci, 4(3B), 524-534. 